\title{
Technological and Financial Assessment of Small Scale Palm Oil Production in Kwaebibrem District, Ghana
}

\author{
S. Adjei-Nsiah ${ }^{1}$, A. K. S. Zu ${ }^{2} \&$ F. Nimoh ${ }^{3}$ \\ ${ }^{1}$ Forest and Horticultural Crops Research Centre, Kade, Institute of Agricultural Research, College of \\ Agriculture and Consumer Sciences, University of Ghana, Legon, Ghana \\ ${ }^{2}$ Center for Entrepreneurship and Enterprise Development, Kumasi Polytechnic \\ ${ }^{3}$ Department of Agric. Economics, Agribusiness and Extension, KNUST, Kumasi \\ Correspondence: S. Adjei-Nsiah, Forest and Horticultural Crops Research Centre, Kade, Institute of Agricultural \\ Research, College of Agriculture and Consumer Sciences, University of Ghana, Legon, Ghana. Tel: \\ 233-245-395-251. E-mail: y_nsiah@yahoo.co.uk
}

Received: March 20, 2012 Accepted: April 9, 2012 Online Published: May 22, 2012

doi:10.5539/jas.v4n7p111 URL: http://dx.doi.org/10.5539/jas.v4n7p111

\begin{abstract}
A study was carried out in the Kwaebibrim District of the Eastern Region of Ghana to study the production practices and the profitability of palm oil production among small scale processors using focus group discussions, semi-structured interviews and participant observations. Three categories of processing equipment namely digester screw press combined, digester with separate hand operated hydraulic press and digester with separate hand operated screw press were found in the district with the latter constituting about $80 \%$ of the processing equipment used by the processors. The major activities involved in the processing of fruits into oil are removal of the fruit containing spikelets from the fresh fruit bunches, fruit loosening and storage, boiling and digestion of fruits and pressing and clarifying of the oil produced. Fruits are usually stored for a period ranging from one to four weeks before processing leading often to high levels of free fatty acids in the oil produced. Due to scarcity of firewood in the district, waste lorry tyres and mesocarp fibres are used in place of firewood generating a lot of smoke with serious health risk to processors and other mill workers and the environment. Constraints in the small scale processing industry include inaccessibility to remunerative market especially during the peak fruit production period of February to May, lack of credit and skills and knowledge in good processing practices. The financial appraisal of palm oil production shows that in the peak fruit production period of April-May, processors make a loss of $38 \%$ of every cedi in sale in their operations and that the production of palm oil can be a profitable venture only during the lean fruit production season (from September - December) when oil is relatively scarce. The study suggests that to improve the income of small scale processors, there is the need to help the processors change their practices through research but at the same time it also requires work to create entry into the existing value chains through policy (e.g. bye-laws).
\end{abstract}

Keywords: processing equipment, free fatty acids, financial analysis, fresh fruit bunches, quality oil

\section{Introduction}

Palm oil is an important domestic and industrial commodity used in the food and the cosmetic industry worldwide. The demand for palm oil is not only growing in the food sector, but also in industry where it is used, for example, for the production of high value cosmetics and luxury soaps. In recent years, palm oil consumption has increased worldwide particularly in Europe, China and India partly because of the expansion of the bio-fuel industry and the need for cheaper sources of oleo chemicals (Inyan, 2002). Consumption of palm oil in Ghana for domestic uses and for industrial purposes (as an ingredient in the production of detergents, soap and cosmetics) exceeds domestic supplies and palm oil and other vegetable oils have been imported for decades (Folds, 2008). Ghana's current requirements for fats and oil are estimated at 252, 432 MT (MPOC, 2009), while the country is only able to produce 232,700 MT of crude palm oil (CPO) annually (MASDAR, 2010). About $80 \%$ of this quantity is produced by small scale processors who use poor processing practices which often results in the production of oil with poor quality in terms of free fatty acid (FFA) content. The CPO produced by this category of processors cannot be utilized by major refineries in Ghana due to its poor quality (high FFA, high moisture content and impurities). This is because crude palm oil with high FFA leads to high losses and increases 
refinery cost during refining. The quality of crude palm oil affects the efficiency and yield of refining and the quality of the fully processed product (Gibon et al., 2007).Thus inspite of the large quantity of CPO produced by small scale processors in Ghana, the country still imports large quantities of palm oil for industrial use while small scale processors find it difficult to sell their CPO during the peak fruit production period of February-May.

Although palm oil processing offers employment to large number of women in Kwaebibrim district, activities involved in small scale processing as well as the profitability of their operations are not known. Information related to processing activities and profitability of small scale palm oil processing may form a basis for designing more appropriate and cost effective processing technologies for the production of good quality palm oil to feed the local industry.

The main objectives of the study were to identify current technology needs of small scale palm oil processors in the Kwaebibrim District and the profitability of their operations. The specific objectives were to (i) examine current processing activities and practices of small scale palm oil processors; (ii) identify constraints in the small scale processing industry (iii) evaluate the profitability of palm oil processing among small scale processors in the district and (iv) draw out implications for developing more sustainable technologies for improving efficiency in small scale processing in order to improve the income of small scale processors.

\section{Materials and Methods}

\subsection{The Study Area and Population}

The study was conducted in ten communities namely; Adonkrono, Kade, Kusi, Subi, Abompe, Damang, Abodom, Asuom, Takorowase and Abaam, in the Kwaebibirem district of the Eastern region of Ghana. The Kwaebibirem district lies within latitudes $6^{\circ} 22^{\prime}$ and $5^{\circ} 58^{\prime} \mathrm{N}$ and longitudes $1^{\circ} 0$ ' and $0^{\circ} 35^{\prime} \mathrm{W}$. The district has Kade as its capital and a population of 179,209 with an annual growth rate of $1.9 \%$ (Year 2000 Census).

Crop farming is the predominant economic activity in the district and thus serves as the source of livelihood for over $72 \%$ of the working population. Major cash crops cultivated in the district are oil palm, citrus and cocoa while plantain, cassava, cocoyam and maize are the major food crops. The number of farmers in the district cultivating oil palm is estimated at 13,095 (Ametepe, District Director of Agriculture, Personal Communication, 2010). Processing of palm fruits is another major economic activity which employs a large section of the working population especially women (Anon, 2009). Several small scale mills are dotted in the various communities in the district. The district is located within the semi-deciduous forest agro-ecological zone of Ghana with annual rainfall amount of about $1500 \mathrm{~mm}$. The soils which are mainly forest ochrosols are silty and silty clay loams. The soils are mostly fertile with moderately acid to neutral $\mathrm{pH}$.

\subsection{Sampling Technique and Sample Size}

Snowball technique was used to make a complete list of all the processing mills in the study area which numbered 62, after which 1 to 6 mills depending on the number of mills in the community were selected from each community. At each mill, random sampling was used to select respondents. Forty mill owners and ninety processors were interviewed. Distribution of mills, number of mills visited and number of processors interviewed in each community is presented in Table 1. Semi-structured interviews and focus group discussions were then used to collect both qualitative and quantitative data. The interviews captured issues on processing practices, processing equipment, source of fruits, labour use and source of market. Information on the cost of operation, revenue from operation, and the constraints in the in the industry were also collected using focus group discussions.

Table 1. Distribution of mills, number of mills visited and number of processors interviewed in each community

\begin{tabular}{lrrr}
\hline Community & Number of mills & Number of mills selected & Number of processors interviewed \\
\hline Kade & 8 & 5 & 10 \\
Subi & 9 & 5 & 10 \\
Adonkrono & 2 & 1 & 4 \\
Kusi & 8 & 6 & 12 \\
Takrawase & 12 & 5 & 14 \\
Abaam & 3 & 3 & 6 \\
Abodom & 3 & 1 & 2 \\
Abompe & 6 & 6 & 16 \\
Daman & 3 & 2 & 4 \\
Asoum & 8 & 6 & 12 \\
Total & 62 & 40 & 90 \\
\hline
\end{tabular}




\subsection{Analytical Methods}

Descriptive statistics such as frequency tables, percentages and graphs were used to analyze both the qualitative and quantitative data on the current processing practices being used by the small scale processors. The profitability of the palm oil processing was evaluated using financial analytical tools such as the profit margins and benefit-cost ratios. The analyses used income and expenditure statements of the 2010 production season of the processors to determine the net returns on the palm oil processing business. The net returns (NR) from the investment were calculated as:

$$
N R=T R-T C
$$

Where, $T R=P_{i} Q_{i}$, and $T C=\sum_{1=0}^{n} P_{X i} X_{i}$

$N R$ is the net return, $T R$, total revenue from sales per ton of palm oil produced, $P i$, price per ton of oil, $Q i$, quantity of sales made, $T C$, total cost of operation per ton of oil produced, $P x i=$ the price of the $i t h$ input, and $X i$ is the ith input (Ross et al., 2001).

The Profit Margin (PM), a financial ratio, was used to measure how efficiently the processors use their assets or how efficiently they manage their operation (Ross et al. 2001). This was used to measure the proportion of income from every cedi in sales. The ratio is given by the net returns divided by sales, i.e. Net returns / Sales. The Benefit-Cost ratios (BCR) was also computed as $\mathrm{BCR}=\mathrm{TR} / \mathrm{TC}$, where $\mathrm{BCR} \geq 1$ implies a viable project.

\section{Results and Discussion}

\subsection{Gender Distribution of Mill Owners and Fruit Processors}

Predominantly, males own and operate most of the palm fruit processing facilities in the Kwaebibirem District. Out of the forty small-scale mills visited in the study area, $80 \%$ of the operators were males while the remaining $20 \%$ were females (Figure 1a). These operators who run the processing unit render services to the processors who are mainly women for a fee. Most of the owners of the mills are not directly engaged in the day to day running of the processing equipment. In many instances, they employ people who run the business for them. Due to the tedious and strenuous nature of the processing activities, these care takers also employ the services of young men who operate the equipment.

Palm oil production is predominantly women's activity with few men engaged in the production. About $89 \%$ of the processors were female while only $11 \%$ were male (Figure $1 \mathrm{~b}$ ). The higher percentage of women involved in oil palm processing is not peculiar only to Ghana. Taiwo et al. (2000) and Akangbe et al. (2008) reported of similar observation in Nigeria. Traditionally, food processing in Ghana is an activity mainly reserved for women. The processing stages in the palm fruit processing outlined in Figure 2 indicate the gender roles at the mill and, most importantly, the employment opportunities offered in small-scale palm oil processing industry in rural Ghana. The less strenuous manual operations, especially the loosening of fruits and sterilization/boiling of fruits, are done by women.

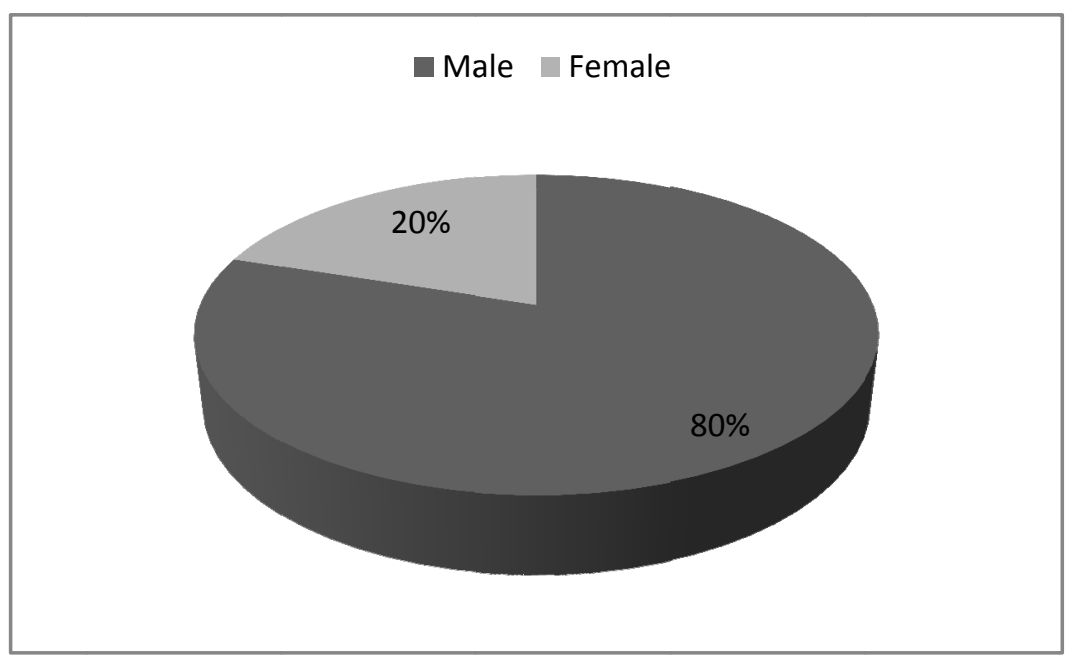

(a) 


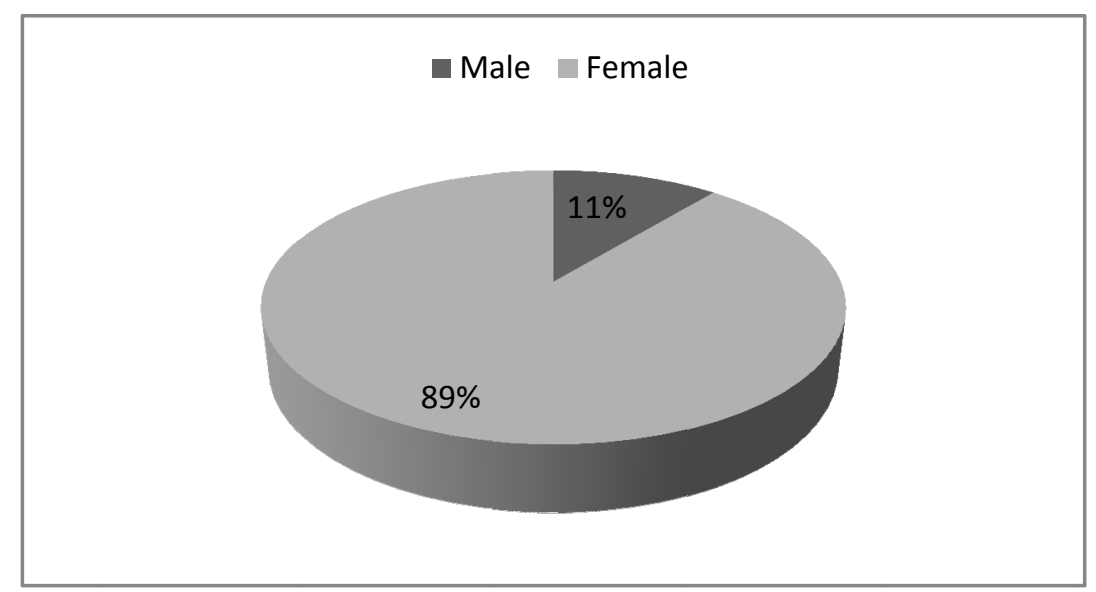

(b)

Figure 1. Gender distribution of (a) Palm Oil Mill Owners and Palm Oil Processors in Kwaebibrim District

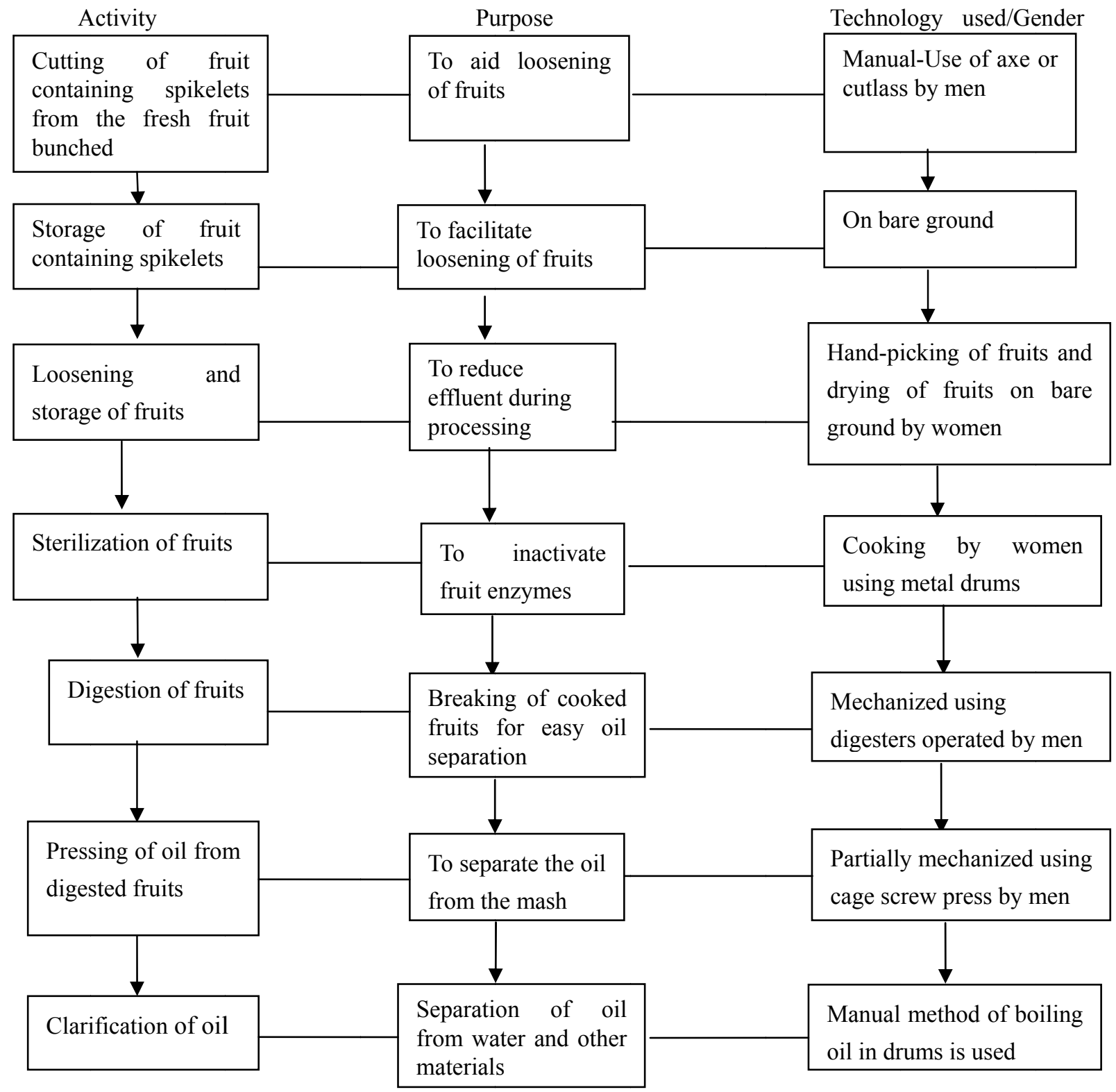

Figure 2. Stages of palm fruits processing by small scale processors in Ghana 


\subsection{Type of Processing Equipment Used}

Three types of processing equipment namely digester with separate hand operated screw press (D/SHOCP), digester with separate hand operated hydraulic press (D/SHOHP) and digester screw press (DSP) were identified in the district (Figure 3). The digester with separate hand operated screw press constitutes about $80 \%$ of the processing equipment found in the district with the digester with separate hand operated hydraulic press and digester screw press constituting 7 and 13\% respectively. The digester with separate hand operated hydraulic press was the first processing equipment to be introduced into the district for the processing of palm oil. According to Poku (2002), manually-operated hydraulic pressers were introduced into Ghana from India to complement the mechanical digesters. With time this has been replaced by the hand operated screw press. However, both manually-operated hydraulic press and the hand operated screw press are less efficient and also less cost-effective in their operations due to time lag between digestion of fruits and pressing of digested fruits for oil, extra labour required to load digested fruits into the cages for pressing as well as the energy needed to operate the press (Poku, 2002). To improve the efficiency and the capacity of processing equipment, the digester screw press was introduced. The digester screw press has several advantages. These include lower production cost because of reduced labour, higher extraction rate and oil yield and women-friendly as it does not require the use of manual pressure for its operation. Despite its advantages, the digester screw press has the following disadvantages;

1. The cost of purchase is high compared with the other two categories of equipment

2. It discharges so much effluent (POME) which is very difficult to manage by the small-scale processors

The popularity of the digester with separate hand-operated screw press could be as a result of its simplicity and probable relative affordability compared to the digester screw press.

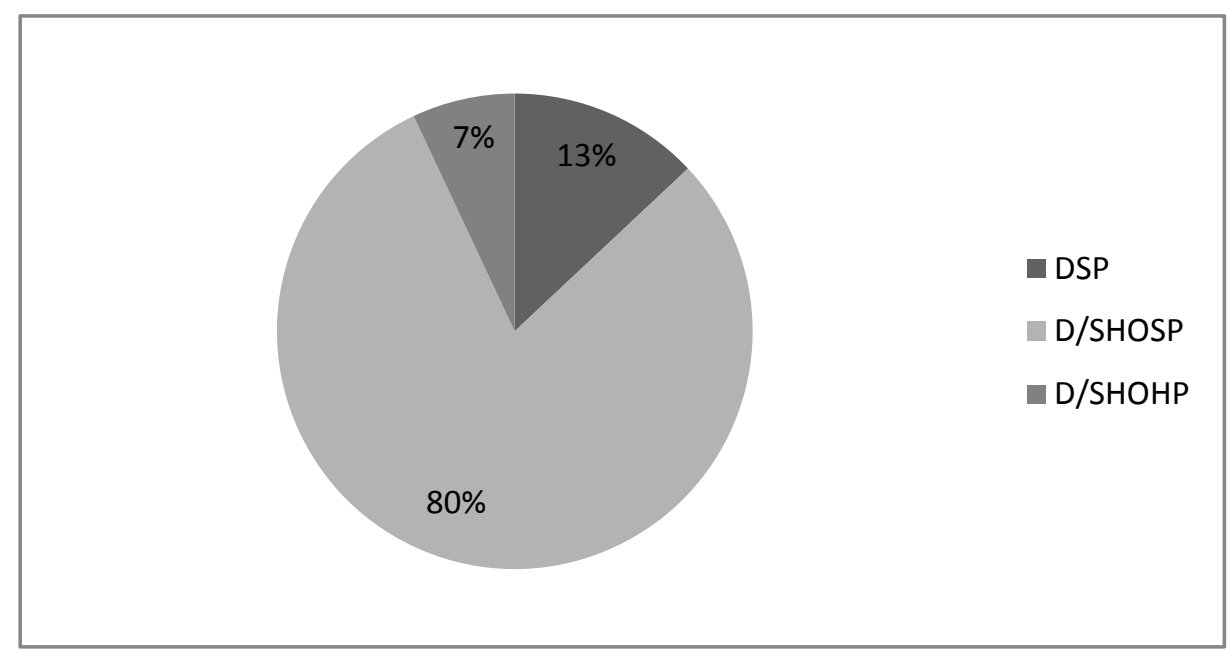

Figure 3. Different type of processing equipment used in Kwaebibrim District

\subsection{Processing Activities and Practices of Processors}

The major operating activities at the mills include removal of spikelets from the bunch, storage of the fruit containing spikelets, fruit removal from spikelets and storage, boiling and digestion of fruits and pressing and clarification of the oil. Of these only digestion and pressing are either fully or partially mechanized.

\subsubsection{Removal of Spikelets from Bunches}

This process involves cutting off the fruit containing spikelets from the fruit bunch using either a cutlass or an axe. This is usually done by men due to its strenuous nature. At every mill there are specialized people who perform this job and they charge between two to three cedis (US\$1.39) per tonne of fresh fruit bunches (FFB). Cutting off the spikelets from the bunch is usually done on the bare floor although it could be easily performed on a raised cemented platform. This activity usually results in fruit bruises which lead to reaction within the oil cells thereby increasing the free fatty acid content of the oil.

\subsubsection{Storage of Spikelet Containing Fruits, Removal and Storage of Fruits from Spikelet}

Storage of spikelet containing fruits is done with the view of facilitating easy loosening or removal of fruits from the spikelets. Spikelets are usually heaped for a period ranging from 3-5 days. Heaping the spikelets causes the 
tissue attaching the fruit to the bunch or spikelet to wilt with time thereby causing the fruit to detach from the spikelet or the bunch.

Removal of fruits from the spikelets is usually done by hands. This activity which is usually performed by women involves picking by hand individual fruits from the spikelets. All the processing facilities visited use this method to remove fruits from the spikelets. This method of fruit picking from spikelets usually delays fruit processing and promote fermentation of fruits resulting in high FFA and oil of low quality. The use of strippers to replace this method will hasten fruit processing and lower FFA content of oil (Babatunde, et al. 1988). Loosening fruits by hand cost between fourteen and fifteen cedis (US\$9.72 and US\$10.42) per tonne of FFB. This activity employs a large section of the unemployed women in the rural communities.

Table 2. Number of processors storing fruits for different period of time before processing in Kwaebibrem District

\begin{tabular}{lcc}
\hline Duration of storage & Frequency & Percentage \\
\hline less than 7 days & 57 & 63 \\
7-14 days & 28 & 31 \\
above 14 days & 5 & 6 \\
Total & 90 & 100 \\
\hline
\end{tabular}

Sometimes, after picking the fruits from the bunch or spikelets, processors further heap the fruits for a period ranging from 1-4 weeks causing the fruits to ferment or grow mouldy. About $37 \%$ of the processors in the district store their fruits beyond one week before processing (Table 2). However, to produce palm oil with low FFA content, Poku (2002) recommends that palm fruits should be processed within 48 hours after harvesting. This is to arrest lypolytic enzymes and stop the production of free fatty acids as poor and lengthy storage of fruits lead to a considerable increase in free fatty acids that will affect the quality of palm oil produced from these fruits (Corley et al., 2003; Owolarafe et al., 2008; Ngando et al., 2011). Processors cite three major reasons for which they store fruits before processing into oil. These reasons include difficulty in removing fruits from the bunch immediately after harvest before boiling, expectation of higher oil yield and reduced effluent resulting from processing. According to the processors, storing the fruits reduce the moisture content of the fruits which consequently leads to low quantity of palm oil mill effluent whose disposal has become an environmental problem in the small scale processing industry. Some processors also erroneously believe that storing the fruits leads to increase in the oil content. They also argue that storing the fruits cause the mesocarp to become soft and easy to press for the release of oil a practice which also leads to low quality of oil as FFA level increases with fermentation (Badmus, 1991; Tan et al., 2009). However, the number of days fruits are stored before processing depends on whether the processor is processing a food or soap-grade palm oil which also depend on the target market. Fruits processed into food-grade oil are usually stored for a duration not exceeding one week while fruits meant for soap-grade oil are stored beyond one week. For instance, processors who produce palm oil for cooking locally known as zomi which has a relatively better quality and sells at a higher price than ordinary CPO (1.5 to 2 times) do not store their fruits beyond one week. On the other hand processors who sell their produce to the Nigerian or the Togolese traders store their fruits beyond two weeks because they assume that palm oil purchased by these traders are used for soap making.

\subsubsection{Sterilization/Boiling of Fruits}

One of the major operations in the processing of palm fruits is fruits boiling or sterilization. The objectives of fruit boiling are: inactivation of enzymes, softening of fruit, conditioning of nuts and coagulation of proteins (Babatunde et al., 2003; Chow \& Ma, 2007). During fruit boiling, the heat inactivates lipase, an active hydrolytic enzyme present in the mesocarp of the fruits. The most popular method for fruit boiling among small scale processors is the use of metal drum over an open fire. Fruits are boiled in metal containers ranging from 200-1000 litres in volume. The fruits are then covered with a jute sack. The metal container is placed on metallic tripod stove with a lot of firewood placed under it. Most of the heat generated is lost to the environment thus requiring a lot of firewood. In most places because of scarcity of firewood, waste lorry tyres and/or mesocarp fibre are used to replace firewood which generates a lot of smoke with serious health risks. Heating may last for 1-3 hours depending on the volume of the fruits and the burning efficiency of the fuel. Most processors prefer lorry tyres because it burns for a longer period and produce a lot of heat. Recently, steam boilers have been designed by the Ghana Regional Appropriate Technology Industrial Services (GRATIS) foundation which uses steam to sterilize the fruits and use less firewood and water. This equipment is however not being widely used by the processors because of cost. Steam boiler with 2 ton of loosed fruits capacity cost about six hundred Ghana cedis (GHC600) or approximately US\$415. 


\subsubsection{Digestion and Pressing of Fruits}

Digestion is the process by which boiled or sterilized fruits are macerated for easy separation of oil from the fibre. This involves crushing and detachment of the heat-weakened mesocarp from fruit nuts. This is the process which is highly mechanized as most of the processing centres in the district visited perform this operation with the aid of a machine. After the fruits are digested, the digested material is pressed to release the oil. This involves separating the crude oil from the mash. Out of the 40 mills visited $80 \%$ use digester with separate hand-operated screw press, $13 \%$ use digester screw press while $7 \%$ use digester with separate hand-operated hydraulic press (Figure 3). With the digester screw press equipment, the digestion and pressing operations are undertaken with the same machine while with the digester with separate screw or hydraulic presses the digestion is done by the mechanical digester and the pressing is done either with a separate hydraulic or screw press. The processing capacity of both the hydraulic and screw presses is limited by the size of the press cage and the mill worker's energy level for operating the equipment. The digester screw press is most economical in terms of labour, material and floor space requirements and also revenue generated. Most mill operators are of the view that the digester screw press is generally too expensive and not within the reach of most small scale mill operators.

\subsubsection{Clarifying}

Oil clarifying is the last processing step in the production of crude palm oil. The purpose of clarifying is to separate the oil from the water and other materials including contaminants. The clarifying process is not mechanized in any of the mills visited. After pressing, the oil is poured into a metal container and placed on a fire and heated for a period ranging from 1 to 2 hours till there is no water in the boiling oil at the top layer. The oil is then removed gradually into metal bucket till there is only a thin layer of oil on the water.

Clarification of the palm oil is not done at some of the processing sites especially at the sites where the palm oil is aimed at the Nigerian and the Togolese markets because processors assume that such CPO would be used for soap making and, therefore, did not need to be clarified. Such oil may contain high moisture levels which will increase FFA content of the oil during storage as a result of autocatalytic hydrolysis (Ngando et al., 2001) making such oil unfit for human consumption.

\subsection{Cost and Revenue from Palm Oil Production}

Results of the financial analysis are presented in Ghana cedis (GH $\phi$ ) (Exchange rate: GH $\phi 1.00=\mathrm{US} \$ 1.45)$. The total cost of production of one ton of crude palm oil in Kwaebibrim District in December 2010 was estimated at GH $\$ 1273.6$ (US\$878.34) (Table 3). Out of this, about $88 \%$ constitute cost of fruits (Table 3). In Nigeria, Ekine and Onu (2008) report that fruit cost constitute 62 and $65 \%$ of the total production cost while Olagunju (2008) reports that fruit cost accounts for about $56 \%$ of the total cost.

The total revenue realised from the sale of one ton of crude palm oil by palm oil processors in December, 2010 amounted to about GHф1600.00 (US\$1103.45) (Tables 4 and 5).

Table 3. Cost of production for 1 ton of crude palm oil in Kwaebibrim district

\begin{tabular}{lr}
\hline Item & Amount (Ghana Cedis) \\
\hline Fresh fruit bunches* & 1120 \\
Operational cost & \\
Transport & 160 \\
Quartering of fruits (Removal of spikelets) & 20 \\
Removal/cleaning of fruits & 24 \\
Loading of fruits into boilers (sterlizers) & 8 \\
Cooking (sterilization of fruits) & 16 \\
Unloading of fruits from boilers & 8 \\
water & 8 \\
milling & 42 \\
Sub-Total & $\mathbf{1 4 0 6}$ \\
Removal of nuts & 18 \\
Pressing of fermented oil from fibre & 9.6 \\
& $\mathbf{2 7 . 6}$ \\
Total Cost & $\mathbf{1 4 3 3 . 6}$ \\
income from sale of kernels & 40 \\
income from sale of fermented oil & 120 \\
& $\mathbf{1 6 0}$ \\
Production cost less revenue from kernel +fermented oil & $\mathbf{1 2 7 3 . 6}$ \\
\hline
\end{tabular}

*Eight tones of fresh fruit bunches are processed to obtain 1 ton of crude palm oil assuming oil extraction rate of $12.5 \%$ (Zu et al., 2012). Exchange rate: US\$1.00 $=$ GH $\not 1.45$ (2010) 
Table 4. Average price of fresh fruit bunches and crude palm oil during the peak and lean fruit production seasons in Kwaebibrim District in 2010

\begin{tabular}{lcc}
\hline Period & \multicolumn{2}{c}{ Price $(\mathrm{GH} \phi) /$ ton } \\
\cline { 2 - 3 } & Fresh fruit bunches & Crude palm oil \\
\hline January-March & 120 & 1200 \\
April-May & 100 & 720 \\
June-September & 120 & 1280 \\
October-December & 140 & 1600 \\
\hline Exchange rate: US\$1.00 $=\mathrm{GH} \phi 1.45(2010)$ &
\end{tabular}

Table 5. Summary of cost and benefit per 1 ton of CPO (@ GH $\notin 1600 /$ ton of CPO) in Kwaebibrim District in December 2010

Exchange rate: US $\$ 1.00=\mathrm{GH} \phi 1.45(2010)$

Given an average price of GH $\phi 1600 /$ ton of CPO (Table 5), the net return on the production of 1 ton of CPO was approximately GH $\notin 326.4$ (US\$225.10) (Table 5). On the average, the palm oil processors in Kwaebibrim generated about GH $\notin 326.4$ as profit on every ton of CPO processed and sold in December, 2010. This represents about $20 \%$ of the income from every cedi in sales. In Nigeria, Olagunju (2008) reports net return per naira of 29.4\% while Ekine and Onu (2008) also report values ranging between 26 and 44\%.

The undiscounted benefit-cost ratio (1.26) which is a measure of project viability showed that production of CPO in the month of December, 2010 was viable demonstrating that CPO production is a lucrative venture (Table 5). However, in the peak production period of April-May, when there is a glut of crude palm oil in the market, the processors produce the $\mathrm{CPO}$ at a loss. For every ton of CPO produced, the processor loses GHC273.6. However, in practice, they do not, since they pay less than they appear to pay for a ton of FFB because of non use of weighing scale for purchasing FFB from farmers. While an average bunch of palm fruits in the district weighs about $15 \mathrm{~kg}$, processors estimate it between $10-12.5 \mathrm{~kg}$ and hence underestimate farmers FFB by as much as about $20 \%$. In most cases processors buy between 80 and 100 bunches for a ton of FFB. When a bunch size is smaller than the average bunch size, two bunches are counted as one. Thus a processor may get between 200-300 kg FFB extra whenever she/he buys a ton of FFB. The small scale processors who process at low extraction rate of between $10-12.5 \%$ have thus survived all these years in the wake of competition with large and medium scale processors partly because they underestimate farmers produce by as much as by $20 \%$ and also partly because the niche market for which they produce do not care so much about quality. One way of increasing the income of small scale processors with a trickling effect to the farmer is to train the processors to produce good quality oil to target the industrial and export markets which are developing fast. Realizing this however requires support and research to help the women processors change their practices but at the same time it also requires work to create entry to existing value chains through policy, for example through bye-laws or setting up a body to regulate the activities of processors to conform to the international standard.

\subsection{Constraints in the Palm Oil Processing Business}

Processors mentioned poor market for processed crude palm oil during peak fruit production season of February-May and high fresh fruit bunches cost during the lean fruit production period of August-December as major constraints in the small scale processing industry. During February-April which is the peak fruit production period, most farmers process their fruits and sell the oil cheaply in the market (Table 6). Therefore processors who purchase fruits and process are not able to compete with these category of processors and therefore sell the oil cheaply often at a loss. During the lean season when fruits are scarce, only processors with huge capital are able to purchase fruits and process although price of crude palm oil is higher during this period. Other constraints mentioned by the processors included lack of credit from financial institutions. The only source of credit they have is the Nigerian traders who at the peak fruit production season advance to them some money to be used for the purchase of fruits for processing. This credit is paid back later during the lean production season in the form of crude palm oil at the prevailing market price of $\mathrm{CPO}$ at the time the money was advanced 
(which is the period of peak production season in February-April). These women usually make a loss because at the time the Nigerian traders would be demanding the oil (which is lean fruit production season of August-December), the price of fruits would have increased such that, the money would not be able to purchase the quantity of fruits that would be needed to produce the quantity of oil demanded by the trader. Thus the women are often trapped in vicious cycle of poverty.

Table 6. Summary of cost and benefit /ton of CPO in Kwaebibrim District from January-December, 2010

\begin{tabular}{lrrrrr} 
& Jan-March & April-May & June-September & October-December & Mean \\
\hline Unit Price $(\mathrm{GH} \phi)$ & 1200.00 & 720.00 & 1280.00 & 1600.00 & 1200.00 \\
Cost $(\mathrm{GH} \phi)$ & 1133.60 & 993.60 & 1145.60 & 1273.60 & 1136.60 \\
PM $(\mathrm{GH} \phi)$ & 66.40 & $(273.60)$ & 134.40 & 326.40 & 63.40 \\
ROI & 0.06 & $(0.28)$ & 0.12 & 0.26 & 0.04 \\
BCR & 1.06 & 0.72 & 1.12 & 1.26 & 1.04 \\
\hline
\end{tabular}

NB: NR, net returns; PM, profit margin; ROI, return on investment; BCR, benefit cost ratio

Exchange rate: US $\$ 1.00=\mathrm{GH} \phi 1.45(2010)$

About $90 \%$ of the processors indicated that they had received no formal training in good processing practices from any organisation. This has resulted in the individual processors' lack of skills and knowledge in good processing practices which often results in the production of crude palm oil of poor quality in terms of free fatty acid content which thus impede their entry into the industrial and the export markets which are expanding fast. This constraint is not only peculiar to small scale palm oil processors in Ghana. In Nigeria, Akangbe et al (2011), also report that lack of training and inaccessibility to extension services are a major constraint to small scale palm oil processing.

In addition, the absence of a regulatory body in the small scale palm oil processing industry to regulate the activities of processors often results in the use of certain environmentally unfriendly and unhealthy practices such as the use of lorry tyres as source of fuel for processing, disposal of effluence into water bodies as well as the use of contaminated water for processing. These practices do not only pose risk to the health of the people who work at the mill including the processors but also the environment.

\section{Conclusion}

The findings of the study suggest that the processing activities of small scale processors in Kwaebibrim district could result in the production of low quality CPO in terms of impurity and FFA content. Small scale processors do not make any effort at improving the quality of the oil they produce because of lack of skills and knowledge about quality and quality is also of little importance in the market they are currently targeting which is buyers from the West Africa sub-Region particularly, Nigeria. The study also suggests that in the peak fruit production period of April-May, processors make very little profit in their operations. One way of improving the income of small-scale processors with a trickling effect to farmers is to train small scale processors to produce good quality oil to target the industrial and export markets which are expanding fast. This could be done by experimenting with small scale processors different methods of processing that could improve both the oil extraction rate and the quality of palm oil produced in terms of FFA content, moisture content and impurities. Improvement in the extraction rate and quality of the crude palm oil produced by the small scale processors will not only reduce wastage of oil in the system but also reduce importation of oil from outside the country as the secondary processors will be able to buy from the small scale processors leading to improved income for both processors and farmers. This will also create an opportunity for small scale processors also to access the international market in rapidly expanding economies such as China. Improving the quality of the palm oil produced by these small scale processors to enable them to have access to remunerative market however requires the collaborative efforts of various actors in the industry including scientists, mill owners, processors, Ghana National Standard Authority and manufacturers.

\section{Acknowledgements}

The authors gratefully thank the two anonymous reviewers who reviewed an earlier version of the manuscript.

\section{References}

Akangbe, J. A., Adesiji, G. B., Fakayode, S. B., \& Aderibigbe, Y. O. (2011). Towards Palm Oil Self-sufficiency in Nigeria: Constaints and Training needs Nexus of Palm Oil Extractors. Journal of Human Ecology, 33(2), 139-145.

Anon. (2009). Ghana districts website (http://www.ghanadistricts.net) the Kwaebibirem district (accessed on 
$02 / 04 / 2010)$

Babatunde, O. O., Ajibola, O. O., \& Ige, M. T. (1988). A Modified Process for Low Cost Palm Oil Extraction. Journal of Food Science and Technology, 25(2), 67-71.

Babatunde, O. O., Ige, M. T., \& Makanjuola, G. A. (2003). Effect of sterilization on fruit recovery in oil palm fruit processing. Journal of Agricultural Engineering Research, 41(2), 75-79.

Badmus, G. A. (1991). NIFOR Automated Small Scale Oil Palm Fruit Processing Equipment--its Need, Development and Cost Effectiveness, PORIM Intl., Palm Oil Conference, Chemistry and Technology, 20-31.

Chaw, M. C., \& Ma, A. N. (2007). Processing of fresh palm fruits using microwaves, International Microwave Institute, 40(3), 165-173.

Corley, R. H. V., \& Tinker, P. B. (2003). The Oil Palm. $4^{\text {th }}$ Ed. John Wiley and sons, Hoboken, New Jersey, USA. Pp. 541.

Cornelius, J. A. (1977). International standards for palm oil. Journal of the American Oil Chemists' Society, 54(12), 943-950.

Ekine, D. I., \& Onu, M. E. (2008). Economics of small-scale palm oil processing in Ikwerre and Etche Local Government Areas of Rivers State, Nigeria. Journal of Agriculture and Social Research, 8(2), 150-158.

Fold, N. (2008). Transnational sourcing practices in Ghana's perennial crop sectors, Journal of Agrarian Change, $8(1), 109$.

Gibon, V., De Greyt, W., \& Kellens, M. (2007). Palm oil refining. European. Journal of Lipid Science and Technology, 109, 315-335.

Inyan, A. (2008). Oil Palm- A Resource With An Emerging Revolutionary Industrial Potential. ACRM Magazine, pp. 6-9.

MASDAR. (2010). Master Plan of the Oil Palm Industry in Ghana. Draft Report for Discussion. MASDAR House, Hampshire, UK.

MPOC, Malaysian Palm Oil Council. (2009). Ghana's Edible Oil Sector Awaits Palm Oil Players. Malaysian Palm Oil Fortune, 4, 5-10.

Ngando, E. G. F., Mpondo, M. E. A., Dikotto, E. E. L., \& Koona, P. (2011). Assessment of the quality of crude palm oil from smallholders in Cameroon. Journal of stored Products and Postharvest Research, 2(3), $52-58$.

Olagunju, F. I. (2008). Economics of Palm Oil Proessing in Southwestern Nigeria. International Journal of Agricultural Economics and Rural Development, 1(2), 69-77.

Owolarafe, O. K., Taiwo, E. A., \& Oko, O. O. (2008). Effect of Processing Conditions on Yield and Quality of Hydraulically Expressed Palm Oil. International Agro-Physics, 22(4), 349-352.

Poku, K. (2002). Small-Scale Palm Oil Processing in Africa, (FAO Agricultural Services Bulletin. 148). Rome Italy, 3-30.

Ross, S, A., Westerfield, R. W., \& Jordan, B. D. (2001). Essentials of Corporate Finance. 3rd Edition McGraw-Hill Book Company.

Taiwo, K. A., Owolarafe, O. K., Sanni, L. A., Jeje, J. O., Adeloye, K., \& Ajibola, O. O. (2000). Technological Assessment of palm oil production in Osun and Ondo States of Nigeria. Technovation, 20, 215-223.

Tan, C., Ghazali, H. M., Kuntom, A., Tan, C., \& Ariffin, A. A. (2009). Extraction and physiochemical properties of low free fatty acid properties crude palm oil. Food Chemistry, 113, 645-650.

Zu, K. S. A., Adjei-Nsiah, S., \& Bani, R. J. (2012). Effect of processing equipment and duration of storage of palm fruits on palm oil yield and quality in the Kwaebibrem District, Ghana. Agricultural Research and Reviews, $1(1), 18-25$. 